\section{Cambodian Reforms in Higher Education Finance}

\section{Zhang Minxuan}

Zhang Minxuan is a doctoral candidate in the Comparative Education Research Center, University of Hong Kong. In November 1997, he completed a consultancy project on "Financing Higher Education and Fee System in Cambodia" for the Cambodian government and the World Bank. Address: CERC, University of Hong Kong, Pokfulam Road, Hong Kong. Fax: 852/2857-9279. E-mail: <mzhang@hkusub.hku.hk>.

A fter 20 years of civil war, Cambodia has begun a period of reconstruction and transition. This transition involves the shift from a one-party dictatorship to multiple-party politics and from a central-command economy to a market-driven one. Between 1990 and 1995 Cambodia's GDP rose from 1.2 to 7.6 percent, and the GDP per capita from U.S.\$130 to U.S.\$287. The market economy and rehabilitation of education have stimulated demand for higher education. Higher education enrollment jumped from 2,357 in 1985 to 13,465 in 1996.

In this context, all nine public higher education institutions and the National Higher Education Task Force-a multiple-ministry reform agency-are eager to reform the financing of higher education. This reform effort contains a few major elements.

The first is an institutional appeal to change the " $\mathrm{min}$ istry-centered finance mechanism" and increase institutional autonomy. Presently Cambodia's nine institutions are controlled by four different ministries. The parent ministries control most or all of the institutions' budgets. Also, each university has to apply to its parent ministry and to the Ministry of Finance and Economics, whenever new facilities are needed-a long and complex process, during which many applications are refused. Partly because of the bureaucratic chain, the institutions are unable, within the relevant fiscal year, to spend their governmental allocations. For instance, in 1995 and 1996 the Faculty of Medicine spent only 42.7 and 52 percent, respectively, of their approved budgets.

Second, the Cambodian government has begun to worry about its overdependence on foreign aid. In 1997 the government's budgetary recurrent expenditure per university student was estimated to be only U.S.\$163. The foreign-aid-based recurrent expenditure per beneficiary was estimated at around U.S.\$350. Capital investment would raise the latter figure further still. For political reasons, the U.S. Agency for International Development and several American universities suspended their aid programs in 1997. Official statistics showed that foreign government aid for Cambodian higher education amounted to 5,054 million riels (U.S.\$2.5 million) in 1994, but only 840 million riels (U.S.\$280 thousand) in 1997. Thus, Cambodian institutions must now generate other income to maintain mini- mum teaching quality.

The third proposed area of financial reform concerns how public higher education institutions develop in competition with private ones. Before the Khmer Rouge era Cambodia had no tradition of private higher education. However, three private universities and colleges have emerged so far during the 1990s. These private institutions claim to provide market-driven curricula and good service. At private Norton University, tuition for a degree course is U.S.\$480 per month and U.S.\$38 per month for a short English-language course. But because the average annual salary is just U.S.\$300, tuition is quite an expense. However, this private university not only attracted students unable to gain admission at public institutions, but also students at public universities who wanted supplementary courses. The majority of full-time students at public universities also paid fees to private institutions for English, computer skills, and management courses as part-time students. In a recent study of 62 respondents from six public institutions, 51 (81.3 percent) report such "private study," paying an average of U.S.\$258 in 1997. Cambodian public higher education institutions face a challenge from private universities.

\section{The government and public institutions are trying to change from a policy of "fee-free" to one of "fee-charging" pub- lic higher education.}

Finally, despite objections, the government and public institutions are trying to change from a policy of "fee-free" to one of "fee-charging" public higher education. Cambodia has a tradition of free higher education plus grants to students in the name of "equal opportunity." Regular students in public universities have traditionally not had to pay for tuition. Even though the enrollment rate was only 1.3 percent in 1997 , the majority of the students came from well-off families, creating a public subsidy in which elite graduates would receive the opportunities of higher income and social status. Now the government has put the introduction of tuition fees on its policy agenda and has invited an international consultancy group to advise on the possible change in tuition policy.

In order to meet the demands of new economic development, nation-building, democratization, and economic liberalization, the Cambodian government put the reform of higher education finance in its first five-year plan, 1996 2000. The reform in higher education finance has political as well as technical implications, however, and will not be easy. 